\title{
Working
}

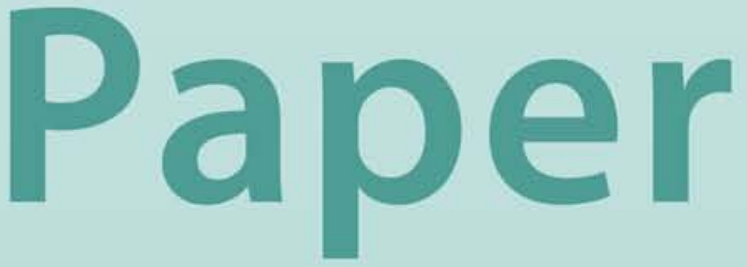




\section{A Markov-Switching Approach to Measuring Exchange Market Pressure}

Francis Y. Kumah 
(C) 2007 International Monetary Fund IMF Working Paper

$\mathrm{WP} / 07 / 242$

Middle East and Central Asia

A Markov-Switching Approach to Measuring Exchange Market Pressure

Prepared by Francis Y. Kumah ${ }^{1}$

Authorized for distribution by Aasim M. Husain

October 2007

\begin{abstract}
This Working Paper should not be reported as representing the views of the IMF. The views expressed in this Working Paper are those of the author(s) and do not necessarily represent those of the IMF or IMF policy. Working Papers describe research in progress by the author(s) and are published to elicit comments and to further debate.

This paper characterizes exchange market pressure as a nonlinear Markov-switching phenomenon, and examines its dynamics in response to money growth and inflation over three regimes. The empirical results identify episodes of exchange market pressure in the Kyrgyz Republic and confirm the statistical superiority of the nonlinear regime-switching model over a linear VAR version in understanding exchange market pressure. The nonlinear empirical approach adequately characterizes the data generation process and yields results that are consistent with theoretical predictions, particularly the dampening effect of monetary contraction on depreciation pressure. During periods of appreciation pressure, however, the reverse policy option - monetary expansion - may not be efficient, particularly where PPP rather than UIP drives exchange rates. In addition, monetary expansion in such cases defeats the primary objective of monetary policy_price stability — and may exacerbate the instability.
\end{abstract}

JEL Classification Numbers:C32, E52, F31, F41.

Keywords: Exchange market pressure, Markov-switching models, monetary policy.

Author’s E-Mail Address: fkumah@imf.org

\footnotetext{
${ }^{1}$ The paper benefited from helpful discussions with my colleagues at the IMF, particularly Aasim Husain, Koffie Nassar, Nkunde Mwase, Paulo Neuhaus, Tapio Saavalainen, and Ahmed Zorome. Excellent research assistance provided by Malina Savova is gratefully acknowledged. My sincere thanks go to Shiu-Shen Chen (of National Taiwan University) for sharing his paper and Gauss codes with me. I, however, remain responsible for any errors and omissions.
} 
I. INTRODUCTION...........................................................................................................................

II. DEFINING EXCHANGE MARKET PRESSURE

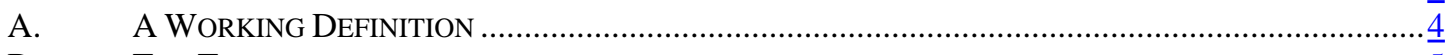

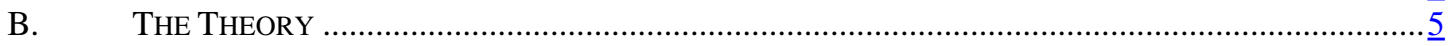

III. CHARACTERIZING EXCHANGE MARKET PRESSURE ..............................................................

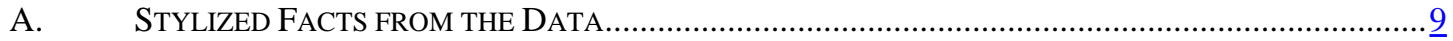

B. CONGRUENT REPRESENTATION OF THE DATA …….........................................................

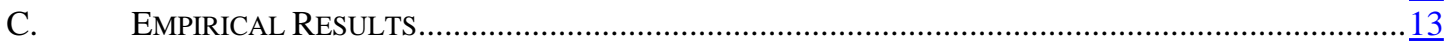

APPENDIX I. DATA SOURCES AND TRANSFORMATIONS ..................................................................

APPENDIX II. MODEL PERFORMANCE AND DURATION PROBABILITIES ....................................23

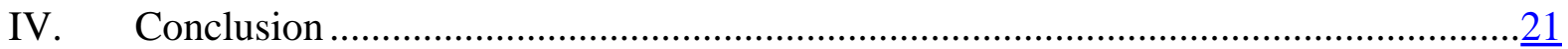

Appendices

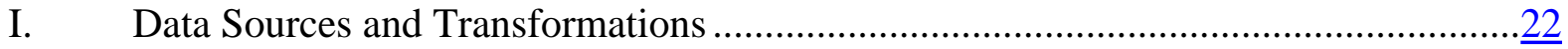

II. Model Performance and Duration Probabilities ..................................................23

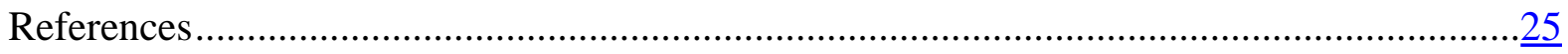

Tables

1. Characterizing Exchange Market Pressure …..................................................... .5

2. Maximum Likelihood Estimation Results, 1996-2006 .......................................15

3. Regime Properties of Exchange Market Pressure, 1996-2006.................................16

Figures

1. Kyrgyz Republic: Consumer Prices, Net Foreign Reserves and Exchange Rates,

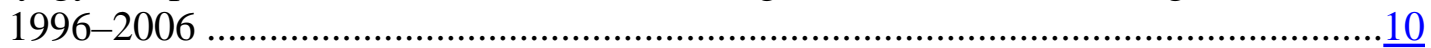

2. Kyrgyz Republic: Dating Exchange Market Pressure, 1995-2006 ..........................13

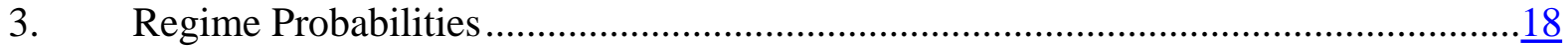

4. $\quad$ Regime-dependent Impulse Response Functions ….........................................19

5. Response of the System after Regime Shifts ................................................ 


\section{INTRODUCTION.}

Following the financial crises in Southeast Asia, Argentina, Mexico and Russia, economists have analyzed exchange market pressure (EMP) using various theoretical models and empirical specifications. ${ }^{2}$ Despite these earlier efforts and the existence of a large theoretical literature on the vulnerabilities of fixed and managed exchange rate regimes to speculative attacks, empirical studies on exchange rate crises are few and far between. In addition, most EMP-related analyses adopt linear econometric methods, except perhaps in the literature on speculative attacks, suggesting that the economy is continuously in either an appreciation state or a depreciation state- thus, ruling out periods of normal exchange rate movements during which the exchange rate responds to economic fundamentals. These empirical approaches may have been subject to misspecification errors that yielded theory-inconsistent results. Thus, empirical work has not yet fully provided satisfactory answers to the question of the impact of the monetary stance on exchange market pressure. This paper suggests a nonlinear approach that sidesteps the shortfall of earlier approaches by adopting a threeregime Markov-switching EMP model in line with Hamilton's 1990 pioneering paper that uses a two-regime Markov-switching model to investigate swings in the dollar against the French franc, the German mark, and the British pound.

It is worth noting, however, that some research on speculative attacks (see for example, Cerra and Saxena, 2002) and the empirical relationship between the monetary stance and EMP (see for example Chen, 2006) integrate the discontinuity in EMP and use nonlinear econometric methods. This paper contributes to the discussion on two broad fronts. First, it defines exchange market pressure as reflecting episodes of sharp exchange rate changes and large central bank intervention fueled by excess foreign exchange demand or supply. In contrast to Hamilton 1990, the setup in this paper allows for periods of normal exchange rate movements in response to changes in economic fundamentals. Second, based on this definition of EMP, the paper specifies and estimates Markov transition probabilities of being in an appreciation regime, a regime of normal exchange rate movements, or a depreciation regime. This specifcation of EMP as a nonlinear regime-switching phenomenon helps to characterize exchange rate dynamics within regimes and during the transition between regimes, in response to the monetary stance, inflation and interest rate differentials. More importantly, it sheds light on the significance of monetary contraction, or interest rate increases, in helping contain depreciation pressure - a question that has received much attention in the empirical literature on currency crises but remains to be definitively resolved - and investigates the evolution of appreciation pressure.

Empirical results from the paper confirm the statistical superiority of nonlinear Markovswitching models over linear vector autoregressive models in charaterizing exchange market pressure and explaining co-movements between money (or credit conditions) and exchange market pressure. Further, it turns out that the EMP identification scheme adopted by the nonlinear empirical specification yields results that are consistent with theroetical

\footnotetext{
${ }^{2}$ There were earlier EMP-related analyses of Canadian monetary policy and movements in the Canadian dollar against the U.S. dollar; see for example Weymark, 1995.
} 
predictions, in particular, the results confirm the prediction that monetary contraction (or increasing interest rates) during periods of depreciation pressure can help restore normalcy in the foreign exchange market. ${ }^{3}$ But monetary expansion may not be a plausible policy option in the case of appreciation pressure, particularly in countries with limited role of uncovered interest parity in exchange rate dynamics. In such cases, monetary expansion defeats the primary objective of monetary policy_-price stability - and could instigate further foreign exchange market instability. Nor does monetary contraction through the use of indirect control instruments (such as open market operations and interest rate changes) help resolve the problem, since monetary contraction through such means only increases the desirability of the domestic currency and exacerbates the appreciation pressure. However, policies that limit foreign exchange market intervention and thereby reduce monetary expansion would dampen appreciation pressure while also helping reduce inflation.

The rest of the paper is set up as follows. Section 2 models exchange market pressure as a nonlinear process and reviews the theory. Section 3 presents some stylized facts from Kyrgyz data and argues for its relevance in understanding exchange market pressure. It also sumarizes empirical results from a congruent Markov-switching representation of comovements of exhange market pressure, the monetary policy stance and inflation in the Kyrgyz Republic. Finally, the concluding section summarizes the empirical findings and draws policy lessons for the Kyrgyz Republic.

\section{Defining Exchange Market Pressure}

\section{A. A Working Definition}

Exchange market pressure has been variously defined in the literature, but the most commonly used definition sees EMP as an excess money phenomenon driven by abnormally large excess domestic currency demand or supply, which forces the monetary authorities to take measures to stem disruptive appreciation or depreciation of the currency. Defined this way, EMP reflects monetary disequilibrium that drives the demand for a safe-haven currency, and may be exercebated by foreign exchange market intervention. Thus, the defining elements of EMP essentially include the simultaneous occurrence of excess demand or supply of a currency and deliberate policy action by the monetary authorities to "lean against the wind" and prevent the currency from appreciating or depreciating. Following the literature (see for example Girton and Ruper, 1977, and Weymark, 1997 and 1998), we derive and characterize EMP in the next section as driven by excess demand or supply of the domestic currency. The literature derives EMP as the sum of exchange rate changes and international reserve accumulation, with little regard to the dynamic relationship between exchange rate changes and intervention by monetary authorities during EMP episodes, or

\footnotetext{
${ }^{3}$ Radetlet et. al., 1998, and Furman and Stiglitz, 1998, conclude that monetary contraction tends to exacerbate exchange market pressure during periods of speculative attacks. Other researchers, including Tanner, 2001, and Goldfajn and Gupta, 1998, find contrary results, albeit in a linear setup. Using a nonlinear regime-switching methodology, Chen, 2001, finds evidence supporting a negative relationship between exchange rate volatility and monetary contraction during currency crisis.
} 
periods of speculative attacks. We extend the definition in the literature by introducing nonlinearities that help distinguish among three regimes - periods of depreciation pressure, normal exchange rate movements and appreciation pressure. In what follows, we explain the essential defining characteristics of EMP as presented in Table 1 below, where $e_{t}$ denotes the domestic price of a unit of foreign currency and $R_{t}$ is the level of foreign exchange reserves (scaled by domestic reserve money), such that $\Delta e_{t}$ and $\Delta R_{t}$ indicate percent changes in the exchange rate (with a positive change depicting depreciation) and foreign reserves, respectively. It is clear from Table 1 that exchange market pressure evolves in a nonlinear fashion and, therefore, requires nonlinear econometric methods to efficiently uncover its characteristics.

Table 1. Characterizing Exchange Market Pressure

\begin{tabular}{|c|c|c|}
\hline & Appreciation $\left(\Delta e_{t}<0\right)$ & Depreciation $\left(\Delta e_{t} \geq 0\right)$ \\
\hline Accumulating Reserves $\left(\Delta R_{t}>0\right)$ & $\begin{array}{c}\text { Appreciation pressure } \\
\text { (Measured using a PPP- } \\
\text { based index or a UIP- } \\
\text { based index) }\end{array}$ & $\begin{array}{l}\text { Normal exchange rate- } \\
\text { Money relationship } \\
\text { (Modeled using a Portfolio } \\
\text { Balance Model or a } \\
\text { Monetary Model of } \\
\text { Exchange Rate } \\
\text { Movements) }\end{array}$ \\
\hline Decumulating Reserves $\left(\Delta R_{t} \leq 0\right)$ & $\begin{array}{l}\text { Normal exchange rate- } \\
\text { Money relationship } \\
\text { (Modeled using a Portfolio } \\
\text { Balance Model or a } \\
\text { Monetary Model of } \\
\text { Exchange Rate } \\
\text { Movements) }\end{array}$ & $\begin{array}{c}\text { Depreciation pressure } \\
\text { (Measured using a PPP- } \\
\text { based index or a UIP- } \\
\text { based index) }\end{array}$ \\
\hline
\end{tabular}

\section{B. The Theory}

As stated above, the incidence of exchange market pressure requires the simultaneous occurence of exchange rate appreciation or depreciation and a conscious effort by the monetary authorities to lean against the wind. Such a constellation of characteristics is adequately captured in the literature, which is based mainly on the monetary model of exchange rate movements and speculative behaviour of agents in the foreign exchange market (see for example, Weymark 1995). Following Eichengreeen et. al. 1994 and 1995, and Pentecost et al. , 2001, this paper integrates uncovered interest parity (and by implication, the assumption of nonperfect substitutability between domestic and foreign assets) as the main factor influencing agents' portfolio choice decision. The specifcation 
allows introduction of interest rate differentials as one of the components of exchange market pressure.

Suppose agents' real money balances $\left(m_{t}^{d}-p_{t}\right)$ can be specified as a log-linear function of income $\left(y_{t}\right)$ and domestic interest rates $\left(i_{t}\right)$, as follows:

$$
m_{t}^{d}-p_{t}=\alpha y_{t}-\beta i_{t}+v_{t}
$$

where $\alpha$ is the income elasticity of money, $\beta$ is the interest semi-elasticity of money, and $v_{t}$ is an unticipated money demand shock variable. Assuming a complete pass-through of foreign inflation to domestic prices through the exchange rate (defined here as the domestic price of foreign exchange) such that absolute purchasing power parity (PPP) holds, and agents' portfolio choice decisions are governed by uncovered interest parity (UIP), equation (1) can be expressed as

$$
m_{t}^{d}=\left(e_{t}+p_{t}^{*}\right)+\alpha y_{t}-\beta\left(i_{t}^{*}+E\left(\Delta e_{t+1} \mid I_{t}\right)\right)+v_{t}
$$

where $p^{*}$ denotes foreign prices and $i^{*}$ is the foreign interest rate. The expression in the first bracket captures PPP and that in the second bracket reflects UIP, $e_{t}$ is the nominal exchange rate (defined as the domestic price of foreign currency), and $\mathrm{E}$ is the expectations operator, such that $E\left(\Delta e_{t+1} \mid I_{t}\right)$ denotes expected future exchange rate change given information up to and including the current period. The domestic money supply is made up of domestic credit $\left(d_{t}\right)$ and foreign reserves $\left(r_{t}\right)$, so that assuming a multiplier of unity, can be expressed as

$$
m_{t}=d_{t}+r_{t}
$$

Further, we assume the monetary authorities intervene in the foreign exchange market by selling and purchasing foreign exchange in accordance with the rule

$$
\Delta r_{t}=-\chi \Delta e_{t}
$$

Likely magnitudes of the intervention parameter, $\chi$, are explained below. Under this rule, the authorities intervene in the foreign exchange market by purchasing (or selling) foreign exchange if they view exchange rate movements as exhibiting appreciation (or depreciation) pressure (see Table 1). Of course, under a freely floating exchange rate regime, $\chi$ is exactly equal to zero and the exchange rate is assumed to move only in accordance with changes in economic fundamentals.

Taking first differences through equations (2) and (3), and noting that $E\left(\Delta e_{t+1} \mid I_{t}\right)$ can be respecified as $E\left(e_{t+1} \mid I_{t}\right)-e_{t}$, yields changes in money demand and money supply equations, respectively, as follows

$$
\Delta m_{t}^{d}=\Delta e_{t}+\Delta p_{t}^{*}+\alpha \Delta y_{t}-\beta \Delta i_{t}^{*}-\beta E\left(\Delta e_{t+1} \mid I_{t}\right)+\beta \Delta e_{t}+\Delta v_{t}
$$




$$
\Delta m_{t}^{s}=\Delta d_{t}+\Delta r_{t}
$$

Given this characterization of the money market, the equilibrium exchange rate can be derived as a function of the economic fundamentals and the degree of foreign exchange market intervention - in effect, the magnitude of $\chi$ - as below.

$$
\Delta e_{t}=\frac{1}{(1+\beta+\chi)}\left(-\Delta p_{t}^{*}-\alpha \Delta y_{t}+\beta \Delta i_{t}^{*}+\beta E\left(\Delta e_{t+1} \mid I_{t}\right)-\Delta v_{t}+\Delta d_{t}\right)
$$

From equation (7) above, we infer standard exchange rate behaviour consistent with the theoretical literature (see for instance Dornbusch, 1976, and Branson and Hendersen ,1985) where, in the absence of intervention by the monetary authorities, (i) increases in the foreign price level appreciates the domestic currency, (ii) increases in domestic productivity or output reduces domestic demand for foreign currency and appreciates the domestic currency vis-a-vis the currencies of trading partners, (iii) increases in foreign interest rates lead to depreciation of the domestic currency, and (v) the domestic currency appreciates in response to a positive domestic money demand shock that increases domestic interest rates but depreciates in response to expansionary money supply shocks.

Changes in the exchange rate depend, to a large extent, on the intervention response coefficient, $\chi$. Notice that $\lim _{\chi \rightarrow \pm \infty} \Delta e_{t}=0$, indicating that the central bank can use direct intervention to hold the exchange rate fixed; more specifically, as $\chi \rightarrow-\infty$, the exchange rate change approaches zero from above, which implies that the central bank sells foreign exchange to keep the domestic currency from depreciating. The opposite situation pertains as $\chi \rightarrow \infty$ - the exchange rate change approaches zero from below, implying that the central bank purchases foreign exchange to stem appreciation pressures. In the absence of foreign exchange intervention (i.e. for $\chi=0$ ), the central bank allows the domestic currency to float freely in response to economic fundamentals and expectations. Further, values of $\chi$ between zero and $\infty$ denote intermediate intervention policies, where the central bank dampens appreciation or depreciation pressure by purchasing or selling foreign exchange. The central bank aggressively leans against the wind when $\chi<-(1+\beta)$, and magnifies exchange rate changes when $-(1+\beta)<\chi<0$.

Having characterized the relationship between intervention and exchange rate movements, we move on to define EMP. ${ }^{4}$ We adopt the Weymark 1998 definition of EMP as "excess demand for the domestic currency in internatonal markets," and specify EMP as the sum of

\footnotetext{
${ }^{4}$ Weymark, 1998, states that EMP does not arise under a freely floating exchange regime, since the exchange rate adjusts quickly to restore equilibrium in the demand and supply of the domestic currency in the international market. Under fixed exchange rate regimes, international reserve holdings are changed to restore equilibrium. Under intermediate regimes, such as managed float regimes, disequilibrium in the demand and supply of the domestic currency in the international market are removed through changes in the exchange rate, foreign reserves and domestic credit.
} 
the percent change in the exchange rate $\left(\Delta e_{t}\right)$ and the change in foreign exchange reserves relative to the monetary base $\left(\Delta r_{t}\right)$, as below:

$$
E M P_{t}=\Delta e_{t}+\eta \Delta r_{t}
$$

where $\eta$ is assumed to be negative. Note that this formula applies only in cases where there is no sterilization of the impact of the foreign exchange market intervention on monetary aggregates. When foreign exchange market intervention is fully sterilized, the monetary disequilibrium channel (through which excess money demand or supply affects exchange rate movements through higher or lower interest rates and inflation) becomes ineffective. Thus, under our characterization, fully sterilized interventions would not instigate exhange market pressure, even though their impact effect may cause short-term changes in exchange rates. In a country where the monetary authorities intervene in the foreign exchange market, EMP as defined in equation (8) will depend importantly on the characterizations presented in Table 1. In particular, we rewrite the EMP equation above, using equation (4), such that:

$$
E M P_{t}=(1-\eta \chi) \Delta e_{t}
$$

where $\eta \in[-1,0)$ and $\chi$ can take on various values, as discussed earlier. Notice that equation (9) underlines the significance of the nonlinear relationship between the degree of intervention $(\chi)$ and foreign reserve elasticity of exchange rates $(\eta)$ in characterizing exchange market pressure. It also reveals, in conjunction with Table 1 , the discontinuity of EMP over time, implying inherent nonlinearities stemming from discrete shifts in the exchange rate process. Therefore, in contrast to Tanner, 2001 and Weymark 1995, 1997, and 1998, who define EMP using variations of equation (8), we adopt a nonlinear specification of EMP in consonance with discussions so far, such that

$E M P\left\{\begin{array}{l}<0, \text { for } \chi \neq 0, \chi \in(-(1+\beta), \infty), \text { and } \Delta e_{t}<0 \text {; indicating appreciation pressure } \\ =0, \text { for } \chi=0 ; \text { indicating a regime of normal exchange rate movements } \\ >0, \text { for } \chi \in(-\infty,-(1+\beta)) \text { and } \Delta e_{t}>0 \text {; indicating depreciation pressure }\end{array}\right.$

Our approach allows a nonlinear derivation of the EMP using Table 1 and equation (10) and applies nonlinear econometric methods to characterize exchange market pressure and its comovements with inflation, interest rates and money growth. We also uncover the dynamic features of EMP during the regimes depicted in equation (10) as well as in the transition to these regimes. We adopt a three-step procedure in the empirical implementation of the approach as follows:

- $\quad$ First, following Edwards (2002) and using equation (8), derive the EMP indicator as the average of changes in the exchange rate and reserves such that both components have equal sample second moments: $\Delta e_{t}-\frac{M_{\Delta e \Delta e}}{M_{\Delta R \Delta R}} \Delta R_{t}$, where $M_{\Delta e \Delta e}$ and $M_{\Delta R \Delta R}$ are sample second moments of changes in the exchange rate and reserves, respectively; 
- $\quad$ Second, identify the various regimes, using Table 1. In this paper, we derive a state variable $\left(\mathrm{STATES}_{\mathrm{F}}\right.$ ), which takes on the values 0,1 or 2 depending on whether the constellation of exchange rate changes and intervention point to a state of depreciation pressure, normal exchange rate movements or appreciation pressure, respectively. A state is labelled to have appreciation pressure if a decline in the exchange rate and interventionist foreign exchange purchases occur simultaneously and exceed their respective sample means. In the converse case, where exchange rate changes are positive and there are interventionist sales of foreign exchange, and both changes exceed their respective sample means, we have a state of depreciation pressure.

- $\quad$ and finally, we use the state variable derived in (ii) above to identify and date the three regimes, estimate their transition properties (including probabilities and duration) and characterize their evolution using a Markov-switching econometric methods.

Our approach contributes to the literature in two main ways - it (i) redefines EMP as a nonlinear phenomenon, and (ii) uses nonlinear Markov-switching econometric methods that were popularized by Hamilton, 1989 and 1990, to characterize its dynamic features and comovements with its determinants.

\section{Characterizing Exchange Market Pressure}

This section applies the three-step procedure outlined in section II above to review and characterize the evolution of exchange market pressure in the Kyrgyz Republic during 19962006. The Kyrgyz Republic is of particular interest here because of the country's recent experience of appreciation pressure-following heightened increases in remittances from Kyrgyz workers in Kazakhstan and Russia, and foreign interest in the banking sector that have led to large inflows of foreign exchange. At the same time, the policymakers have been confronted on occasions with exchange market pressure to which they responded with massive interventions. For example, during the Russian 1998 financial crisis and the 2005 Tulip Revolution the som depreciated against the dollar while the National Bank lost reserves trying to avert the depreciations. By contrast, the Bank accumulated large amounts of foreign reserves during the last quarter of 2006 in attempts to resist appreciation pressure.

Following Hamilton, 1990, we posit that the evolution of exchange market pressure is charatcerized by regime-specific dynamics that can be uncovered using a nonlinear Markovswitching VAR (MSVAR). We exploit recent developments in the MSVAR literature (see for example Chen, 2006 and Krolzig and Toro, 1999, which contrast with the linear approaches of Tanner and Weymark) and estimate impulse response functions of exchange rate changes to selected monetary variables, such as changes in money growth, inflation and interest rate differentials. The objective is to throw more light on the relationship between the monetary stance and exchange market pressure.

\section{A. Stylized Facts from the Data}

Exchange market pressure as defined above, is rare in the literature. It manifested itself during the Southeast Asian, Argentinean, Mexican, and Russian financial crises, when the 
currencies of these countries came under immense depreciation pressure. Of particular interest, is the Russian 1998 financial crisis, which affected many countries of the Commonwealth of Independent States that witnessed initial large appreciations of their currencies against the rubble but had to let go eventually and depreciated, along with the ruble, against the dollar. Nonetheless, isolated incidences of recent monetary and exchange rate developments in the Kyrgyz Republic, offer good insight into the evolution of exchange market pressure. As shown in Figure 1 below, exchange rate movements in the Kyrgyz Republic tended to mirror inflation developments in 1996-2006.

Figure 1. Kyrgyz Republic: Consumer Prices, Net Foreign Reserves and Exchange Rates, 1996-2006 (12-month percent changes)

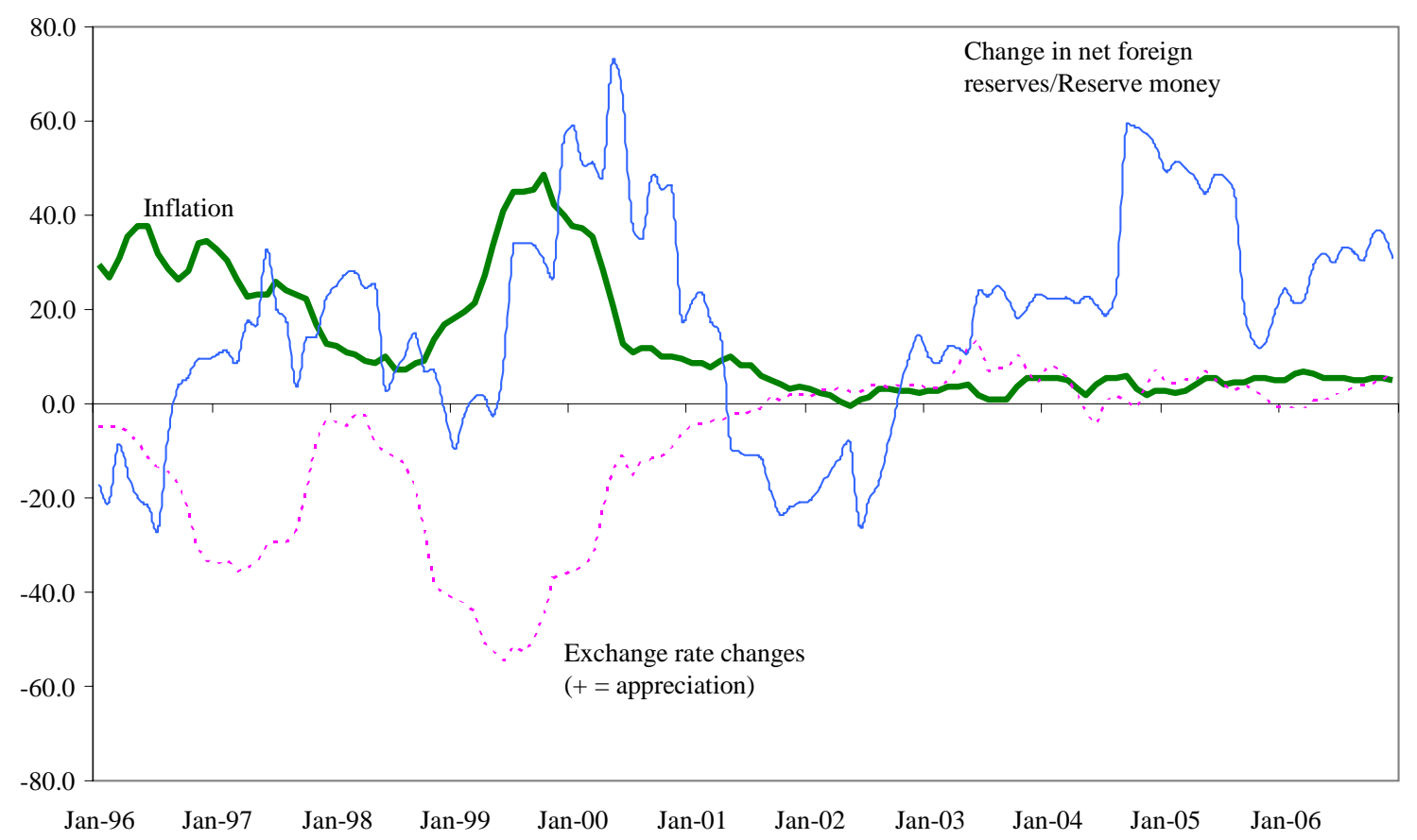

The relationship between foreign reserve accumulation and exchange rate movements during the period is not clear. However, the simultaneous occurrence of slower depreciation together with reserve accumulation in 1999-2000 (when the rate of depreciation declined continuously, following the Russian financial crises) and of appreciation with massive reserve accumulation since late 2002 suggest that there could well have been degrees of exchange rate pressure during these periods. We leave this to the econometric exercise to uncover, but developments in 2005-06 deserve particular mention because they clearly indicate the presence of exchange market pressure. The domestic currency appreciation slowed down during the second half of 2005 (i.e. in the immediate aftermath of the Tulip Revolution), prompting an increase in inflation and loss of reserves through intervention. At the beginning of 2006, however, the currency tended to appreciate, helped by large remittance inflows and foreign interest in the domestic banking sector. By the end of 2006, the som had appreciated by 8 percent, and the National Bank accumulated large amounts of foreign reserves mainly through intervention (amounting to about a third of reserve money at end 2006) aimed at moderating the currency appreciation. The large unsterilized intervention 
lead to a rapid expansion in reserve money, but inflation tended to decline as the currency appreciated.

\section{B. Congruent Representation of the Data}

Following the literature, we specify a Markov-switching VAR model to explain the evolution of exchange market pressure in the Kyrgyz Republic during 1995-2006. Consider the observed time series vector $y_{t}=\left(\Delta e_{t}, \Delta p_{t}, \Delta m_{t}\right)$ ' -where the variables denote changes in the exchange rate (defined such that an increase denotes domestic currency appreciation), consumer prices and broad money - evolves according to a time-varying state-dependent process (with unobservable discrete regime variable, $s_{t} \in\{1, \ldots, M\}$ ), as specified in equation (11) below: ${ }^{5}$

$$
y_{t}-\mu\left(s_{t}\right)=A_{1}\left(s_{t}\right)\left(y_{t-1}-\mu\left(s_{t-1}\right)\right)+\ldots+A_{p}\left(s_{t}\right)\left(y_{t-p}-\mu\left(s_{t-p}\right)\right)+u_{t}
$$

where Gaussian error term is conditioned on $s_{t}: u_{t} \mid s_{t} \square N I D\left(0, \Sigma\left(s_{t}\right)\right)$. This is a $p$-th order, M-state Markov-switching vector autoregressive model of the evolution of the exchange rate, inflation, and money growth. The shifts in the parameters, as denoted by $\mu\left(s_{t}\right)$, and $A_{1}\left(s_{t}\right) \ldots, A_{p}\left(s_{t}\right)$, and $\Sigma\left(s_{t}\right)$, describe the dependence of the VAR parameters on the regime variable $\left(s_{t}\right)$, which is assumed to be generated by a discrete state Markov stochastic process defined by the time-invariant transition probabilities:

$$
p_{i j}=\operatorname{prob}\left(s_{t+1}=j \mid s_{t}=i\right), \quad \sum_{j=1}^{M} p_{i j}=1 \forall i, j \in\{1, \ldots, M\} .
$$

According to this model, there is an immediate one-time jump in the process mean after a change in regime. It is also possible to specify a model that assumes that the mean smoothly approaches a new level after the transition to another state. In the literature, the former model is characterized as a Markov mean-switching heteroskedastic vector autoregressive model (MSMH(M)-VAR(p)), while the latter is termed an intercept-switching heteroskedastic vector autoregressive model (MSIH(M)-VAR(p)). Usually, in the latter specification, equation (11) is replaced by

$$
y_{t}=v\left(s_{t}\right)+A_{1}\left(s_{t}\right)\left(y_{t-1}-\mu\left(s_{t-1}\right)\right)+\ldots+A_{p}\left(s_{t}\right)\left(y_{t-p}-\mu\left(s_{t-p}\right)\right)+u_{t}
$$

\footnotetext{
${ }^{5}$ Variable definitions and transformations are presented in Appendix I, the data appendix. In our estimation procedure, we use as one of the explanatory variables a state variable STATES $_{\mathrm{F}}$ as described in our procedure outlined in the previous section. Replacing inflation by the interest rate differential (relative to the United States) yields statistically insignificant coefficients with wrong signs, suggesting that exchange rate movements in the Kyrgyz Republic are driven more by purchasing power parity than by uncovered interest parity.
} 
Dynamic adjustments of the observed variables under the mean-adjustment form in equation (11) and the intercept adjustment form in equation (13) after a change in regime are not equivalent. Unlike under the regime-invariant VAR models, a permanent shift in the mean $\left(u_{t}\right)$ causes an immediate jump of the observed variables, while a similar shift in the intercept term $\left(v_{t}\right)$ is identical to an equivalent shock to the white-noise series, $u_{t}$.

Variants of these specifications are used in the literature on nonlinear macroeconomic dynamics - for an exhaustive description of these approaches see Krolzig and Toro, 1999. In the exchange rate literature, Chen, 2006 and Soledad and Peria, 2002 utilize Markovswitching VAR models in characterizing exchange rate volatility and speculative attacks, with no underlying theoretical model to inform the derivation of regimes. Our approach uses the theoretical characterization of exchange market pressure discussed in section II above to identify periods of depreciation pressure, normal exchange rate movements, and depreciation pressure as three distinct regimes in the evolution of exchange rates, inflation, and money growth. We estimate two Markov-switching three-regime models-MSI(3)-VAR(3) and MSIH(3)-VAR(3), as described above.

Using the first-two steps of our procedure outlined in the previous section, we classify periods in the Kyrgyz Republic between 1996 and 2006 into 3 regimes - of depreciation pressure, normal exchange rate movements, and appreciation pressure, as indicated in Figure 2 by the dark bars, the shaded regions, and the unshaded regions, respectively. The figure gives us a preliminary idea about the various regimes, which can then be used in estimating the regime properties of the data. Notice the limited occurrence of depreciation pressure; as indicated by the dark bars, these periods are concentrated in the earlier parts of the sample period - early and late 1996, early 1997, late 1998 and early 1999 (which coincide with the Russian 1998 financial crisis), and mid-2000. Periods of normal exchange rate movements (indicated by the shaded regions) have dominated the picture, while episodes of appreciation pressure seem to have occurred through out the period but with very short duration. Notice that periods of appreciation pressure during which the exchange rate actually appreciates tend to have longer duration than those that occurred during periods of exchange rate depreciation, or more appropriately, of slower exchange rate depreciation. We exploit these subtle differences in the context of a nonlinear regime-dependent model that amplifies the differences, dates the occurrences of the three regimes, derives transition probabilities, and highlights the empirical richness of the nonlinear approach by characterizing the regime-dependent dynamics of exchange rate changes in response to monetary conditions. 
Figure 2. Kyrgyz Republic: Dating Exchange Market Pressure, 1995-2006 1/

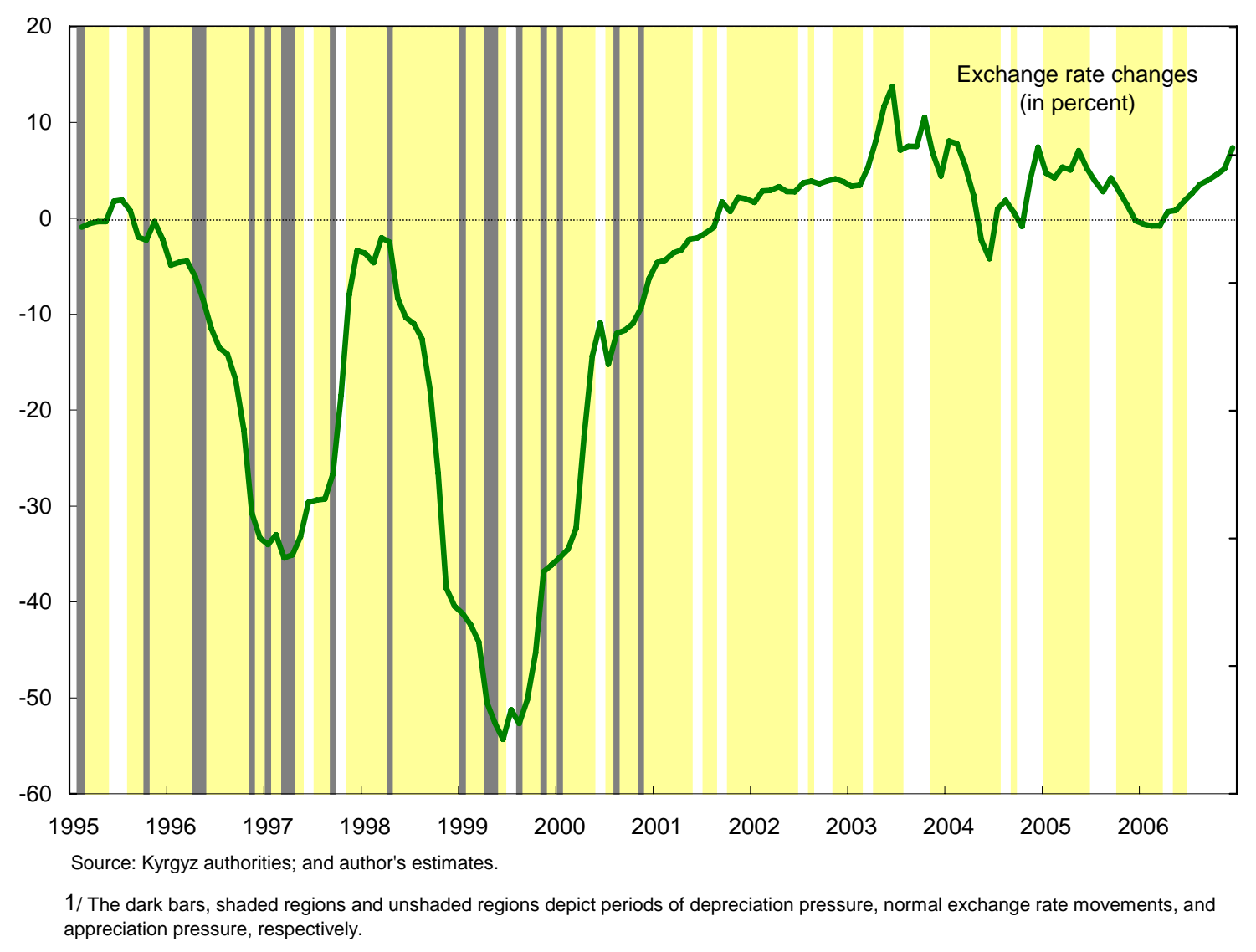

C. Empirical Results

\section{Regime characterization}

Table 2 presents empirical results from the two Markov-switching models-an intercept switching vector autoregressive model with and without regime-dependent variances (i.e., MSIH(3)-VAR(3) and MSI(3)-VAR(3), respectively), as defined in equations (11), (12) and (13), but with constant autoregressive coefficients—using Kyrgyz monthly data from 1996 to 2006. As shown in Figures A1-A3 of Appendix II, the fit of the model is good; for example, the plots of the residuals in Figures A2-A3 indicate the absence of residual autoregression and almost all of the standardized residuals fall within two standard deviations of a zero mean. The estimated coefficients presented in Table 2 indicate that, overall, the nonlinear models fit the data better than a linear VAR counterpart, since the nonlinear models show higher likelihoods. However, the nonlinear model with regime-dependent variances fits the data better than the one with constant variances - the estimated log. likelihood of the former model is higher. Information criteria presented in the table also indicate statistical preference for the nonlinear models over their linear VAR counterpart and of the regime-dependent variance nonlinear model over the model variant with a constant variance. This indicates that variations in variances over the regimes are also important in characterizing exchange market pressure. A likelihood ratio test of the equality of variances $\left(\sigma_{1}^{2}=\sigma_{2}^{2}=\sigma_{3}^{2}\right)$ yields a $\chi^{2}(2)=$ 
112.4, which exceeds the 5-percent critical margin for rejecting the null hypothesis of equality. Consistent with this finding, variations in changes in the exchange rate, prices and money are higher during periods of depreciation and appreciation pressures than during normal exchange rate movements (Table 2). Given this result, we restrict ourselves in the remainder of the paper to discussing only the results from the model with regime-dependent variances (MSIH(3)-VAR(3)). ${ }^{6}$

Further, the estimated regime-dependent intercepts yield interesting and mostly statistically significant results. The results show that regime 1 (depreciation pressure) is characterized by a higher decline in the exchange rate change as well as higher price change and monetary expansion under the regime-dependent variances model than in the other regimes. In fact, regime 2 (normal exchange rate movements) depicts the lowest absolute changes in mean exchange rate and price changes and only a lightly higher mean money growth than under regime 3. Thus, normal periods of exchange rate movements tend to be associated with moderate appreciation of the domestic currency along with low monetary expansion and price changes.

\footnotetext{
${ }^{6}$ The empirical estimations were carried out in Ox (see Doornik, 1999, and Krolzig, 1998, for a description of the approach and the econometric software).
} 
Table 2. Maximum Likelihood Estimation Results, 1996-2006

\begin{tabular}{|c|c|c|c|c|c|c|}
\hline & \multicolumn{3}{|c|}{$\operatorname{MSI}(3)$-VAR(3) } & \multicolumn{3}{|c|}{ MSIH(3) -VAR(3) } \\
\hline & $\Delta e_{t}$ & $\overline{\Delta p_{t}}$ & $\Delta m_{t}$ & $\overline{\Delta e_{t}}$ & $\Delta p_{t}$ & $\Delta m_{t}$ \\
\hline \multicolumn{7}{|c|}{ Regime-dependent intercepts } \\
\hline$v_{1}$ & $\begin{array}{r}-6.359 \\
(-5.923)\end{array}$ & $\begin{array}{r}2.011 \\
(3.642)\end{array}$ & $\begin{array}{l}18.215 \\
(4.011)\end{array}$ & $\begin{array}{r}-5.027 \\
(-5.344)\end{array}$ & $\begin{array}{r}2.679 \\
(3.789)\end{array}$ & $\begin{array}{r}7.256 \\
(2.400)\end{array}$ \\
\hline$v_{2}$ & $\begin{array}{r}-0.516 \\
(-1.169)\end{array}$ & $\begin{array}{r}1.143 \\
(5.227)\end{array}$ & $\begin{array}{r}7.672 \\
(4.062)\end{array}$ & $\begin{array}{r}0.557 \\
(1.304)\end{array}$ & $\begin{array}{r}0.670 \\
(2.599)\end{array}$ & $\begin{array}{r}3.897 \\
(3.127)\end{array}$ \\
\hline$v_{3}$ & $\begin{array}{r}-8.439 \\
(-6.098)\end{array}$ & $\begin{array}{r}6.764 \\
(10.013)\end{array}$ & $\begin{array}{l}30.469 \\
(5.290)\end{array}$ & $\begin{array}{r}-0.665 \\
(-1.427)\end{array}$ & $\begin{array}{r}1.471 \\
(3.072)\end{array}$ & $\begin{array}{r}3.510 \\
(0.421)\end{array}$ \\
\hline \multicolumn{7}{|c|}{ Autoregressive coefficients } \\
\hline$\Delta e_{t-1}$ & $\begin{array}{r}1.312 \\
(14.934)\end{array}$ & $\begin{array}{r}-0.155 \\
(-3.501)\end{array}$ & $\begin{array}{r}0.446 \\
(1.192)\end{array}$ & $\begin{array}{r}1.349 \\
(15.381)\end{array}$ & $\begin{array}{r}-0.145 \\
(-3.005)\end{array}$ & $\begin{array}{r}0.716 \\
(3.854)\end{array}$ \\
\hline$\Delta e_{t-2}$ & $\begin{array}{l}-0.492 \\
(-3.54)\end{array}$ & $\begin{array}{r}0.172 \\
(0.253)\end{array}$ & $\begin{array}{r}0.162 \\
(0.275)\end{array}$ & $\begin{array}{r}-0.704 \\
(-5.195)\end{array}$ & $\begin{array}{r}0.053 \\
(0.711)\end{array}$ & $\begin{array}{r}-0.777 \\
(-2.692)\end{array}$ \\
\hline$\Delta e_{t-3}$ & $\begin{array}{r}0.115 \\
(1.285)\end{array}$ & $\begin{array}{r}0.083 \\
(1.902)\end{array}$ & $\begin{array}{r}-0.370 \\
(-0.986)\end{array}$ & $\begin{array}{r}0.294 \\
(3.313)\end{array}$ & $\begin{array}{r}0.025 \\
(0.517)\end{array}$ & $\begin{array}{r}0.147 \\
(0.792)\end{array}$ \\
\hline$\Delta p_{t-1}$ & $\begin{array}{r}0.354 \\
(2.530)\end{array}$ & $\begin{array}{r}1.056 \\
(15.822)\end{array}$ & $\begin{array}{r}0.093 \\
(0.161)\end{array}$ & $\begin{array}{r}0.039 \\
(0.285)\end{array}$ & $\begin{array}{r}1.151 \\
(13.209)\end{array}$ & $\begin{array}{r}-0.099 \\
(-0.331)\end{array}$ \\
\hline$\Delta p_{t-2}$ & $\begin{array}{r}-0.333 \\
(-1.594)\end{array}$ & $\begin{array}{r}-0.297 \\
(-2963)\end{array}$ & $\begin{array}{r}-1.116 \\
(-1.283)\end{array}$ & $\begin{array}{r}0.052 \\
(0.269)\end{array}$ & $\begin{array}{r}-0.343 \\
(-2.811)\end{array}$ & $\begin{array}{r}0.104 \\
(0.235)\end{array}$ \\
\hline$\Delta p_{t-3}$ & $\begin{array}{r}0.125 \\
(1.076)\end{array}$ & $\begin{array}{r}0.053 \\
(0.946)\end{array}$ & $\begin{array}{r}0.922 \\
(1.910)\end{array}$ & $\begin{array}{r}-0.020 \\
(-0.181)\end{array}$ & $\begin{array}{r}0.020 \\
(0.292)\end{array}$ & $\begin{array}{r}-0.021 \\
(-0.088)\end{array}$ \\
\hline$\Delta m_{t-1}$ & $\begin{array}{r}-0.016 \\
(-0.783)\end{array}$ & $\begin{array}{r}0.003 \\
(0.318)\end{array}$ & $\begin{array}{r}0.707 \\
(8.301)\end{array}$ & $\begin{array}{r}-0.059 \\
(-4.811)\end{array}$ & $\begin{array}{r}0.035 \\
(3.515)\end{array}$ & $\begin{array}{r}0.854 \\
(14.335)\end{array}$ \\
\hline$\Delta m_{t-2}$ & $\begin{array}{r}-0.005 \\
(-0.211)\end{array}$ & $\begin{array}{r}-0.020 \\
(-1.568)\end{array}$ & $\begin{array}{r}-0.198 \\
(-1.816)\end{array}$ & $\begin{array}{r}0.047 \\
(2.630)\end{array}$ & $\begin{array}{r}0.003 \\
(0.227)\end{array}$ & $\begin{array}{r}0.155 \\
(2.653)\end{array}$ \\
\hline$\Delta m_{t-3}$ & $\begin{array}{r}0.017 \\
(0.885)\end{array}$ & $\begin{array}{r}-0.029 \\
(-2.968)\end{array}$ & $\begin{array}{r}0.164 \\
(1.962)\end{array}$ & $\begin{array}{r}-0.005 \\
(-0.296)\end{array}$ & $\begin{array}{r}-0.030 \\
(-2.886)\end{array}$ & $\begin{array}{r}-0.150 \\
(-3.390)\end{array}$ \\
\hline Variances & 5.004 & 1.232 & 92.176 & & & \\
\hline$\sigma_{1}^{2}$ & & & & 8.467 & 6.666 & 33.436 \\
\hline$\sigma_{2}^{2}$ & & & & 4.680 & 1.024 & 17.002 \\
\hline$\sigma_{3}^{2}$ & & & & 1.189 & 2.013 & $1,018.472$ \\
\hline Log. Likelihood & & & & & & \\
\hline $\begin{array}{l}\text { Nonlinear system } \\
\text { Linear system }\end{array}$ & & $\begin{array}{l}-975.172 \\
-1,018.532\end{array}$ & & & $\begin{array}{l}\text { 18.969 } \\
, 018.532\end{array}$ & \\
\hline $\begin{array}{c}\text { AIC/HQ/SC Criteria } \\
\text { Nonlinear system } \\
\text { Linear system }\end{array}$ & $\begin{array}{l}15.987 \\
16.477\end{array}$ & $\begin{array}{l}\text { / } 16.422 / 17 \\
\text { / } 16.803 / 17\end{array}$ & & $\begin{array}{r}15.296 \\
16.477\end{array}$ & $\begin{array}{l}15.840 / 16 \\
16.803 / 17\end{array}$ & \\
\hline
\end{tabular}

Source: Author's estimates, using the Expectations-Maximization (EM) algorithm in Ox.

Note: The numbers indicated in parenthesis are t-values. 
Estimated transition probabilities under the model with regime-dependent variances are presented in the matrix $\mathbf{P}$ below:

$$
P=\left(\begin{array}{lll}
0.939 & 0.000 & 0.061 \\
0.013 & 0.914 & 0.073 \\
0.000 & 0.514 & 0.486
\end{array}\right)
$$

where, as defined above, $p_{i j}=\operatorname{Pr}\left(s_{t+1}=j \mid s_{t}=i\right)$. The estimates show, for example, that there is a 94 percent probability of staying in the depreciation regime, with duration (which is derived as $\frac{1}{\left(1-p_{i j}\right)}$ ) of a year and a half (Table 3 ). They also indicate the empirical implausibility of moving into a depreciation regime from an appreciation regime, but the estimated zero probability of transitioning into a regime characterized by normal exchange rate movements from a depreciation regime seems counterintuitive. Further, the estimated transition probabilities indicate that none of the regimes is permanent, since all the estimated transition probabilities are below one. The estimated ergodic probabilities indicate that the Kyrgyz Republic experienced periods of normal exchange rate changes 73 percent of the time; the regime has been persistent, with 91 percent probability of staying in the normal regime with duration of just under a year. The ergodic probabilities of the depreciation and appreciation regimes are 15 percent and 12 percent, respectively, and the estimated corresponding durations (of 16 months and two months, respectively) are far lower than for the period of normal exchange rate movements. Thus, there have been only a few episodes of depreciation and appreciation pressure in the Kyrgyz Republic during 1996-2006. The forecast $h$-step probabilities of remaining in such regimes drop very quickly to below 25 percent and the duration probabilities regimes are high at low forecast horizons (Figure A4 in Appendix 2).

Table 3. Regime Properties of Exchange Market Pressure, 1996-2006

\begin{tabular}{lccc}
\hline \hline & Observations & $\begin{array}{c}\text { Ergodic } \\
\text { Probability }\end{array}$ & $\begin{array}{c}\text { Expected } \\
\text { Duration }\end{array}$ \\
\hline \hline Model I: MSI(3)-VAR(3) & & & \\
Regime 1: (depreciation pressure) & 19.3 & 0.100 & 3.820 \\
Regime 2: (normal exchange rate movements) & 93.7 & 0.832 & 85.010 \\
Regime 3: (appreciation pressure) & 15.0 & 0.068 & 3.160 \\
Model II: MSIH(3)-VAR(3) & & & \\
Regime 1: (depreciation pressure) & 32.0 & 0.153 & 16.370 \\
Regime 2: (normal exchange rate movements) & 80.7 & 0.726 & 11.590 \\
Regime 3: (appreciation pressure) & 15.3 & 0.121 & 1.950 \\
& & & \\
\hline \hline
\end{tabular}

Source: Author's estimates using the EM algorithm in Ox. 
Estimated regime probabilities for the MSIH(3)-VAR(3) model help to identify the isolated periods of depreciation and appreciation pressure, as reported in Figure 3 below. As explained in the data appendix, the variable names Dxrate, INF12M and Dbm correspond to 12-month changes in the exchange rate, consumer prices, and broad money, respectively. The first panel in Figure 3 shows the evolution of these series, while the second, third, and fourth panels show the filtered, smoothed and predicted probabilities of being in regime 1 (depreciation pressure), regime 2 (normal exchange rate movements), and regime 3 (appreciation pressure), respectively. Regime 2 dominates the observations presented earlier in Figure 2 and this is confirmed by the statistical analysis.

Regime 1 is characterized by two episodes of depreciation pressure in the Kyrgyz Republic - the periods mid-1996-mid-1997, and mid-1998-end 1999 (which includes the period of the Russian financial crisis). The first period is associated with continuous depreciation of the domestic currency in response to high inflation and monetary expansion, while the second period coincided with the developments preceding, during, and after the Russian crisis. During the first period, the som depreciated by a cumulative 38 percent and inflation averaged 17 percent. Contagion effects of the Russian financial crisis dominated developments in the second period. As discussed earlier, during the Russian financial crisis in 1998, the domestic currency came under immense depreciation pressure as the Russian ruble depreciated against major currencies. The som depreciated cumulatively by almost 90 percent between mid-1998 and end 1999, and a large proportion of the depreciation was realized during the last quarter of 1998 - in the midst of the Russian financial crisis.

The approach identifies seven periods of appreciation pressure. The timing of appreciation pressure corresponds closely to those plotted in Figure 2 but three of the seven periods coincide with those identified in the figure-appreciation pressure in mid-2002, late 2005 and the last quarter of 2006. Interestingly, the statistical exercise classifies the period in the immediate aftermath of the 2005 Tulip Revolution—second quarter 2005-as a period of normal exchange rate movements, plausibly because of the limited intervention by the monetary authorities as the som displayed only temporary weakness. The last quarter of 2006 is rightly classified as a period of appreciation pressure driven by huge remittance inflows and heightened foreign interest in the domestic banking sector. During the quarter, the National Bank purchased \$186 million (equivalent to a third of end-2006 reserve money). Notwithstanding the intervention, the domestic currency appreciated by 8 percent in nominal terms, although it remained roughly unchanged in real effective terms, due to a weakening of the dollar and subsequent appreciation of trading partner currencies (notably the Kazakh tenge and the Russian ruble). 
Figure 3. Regime Probabilities

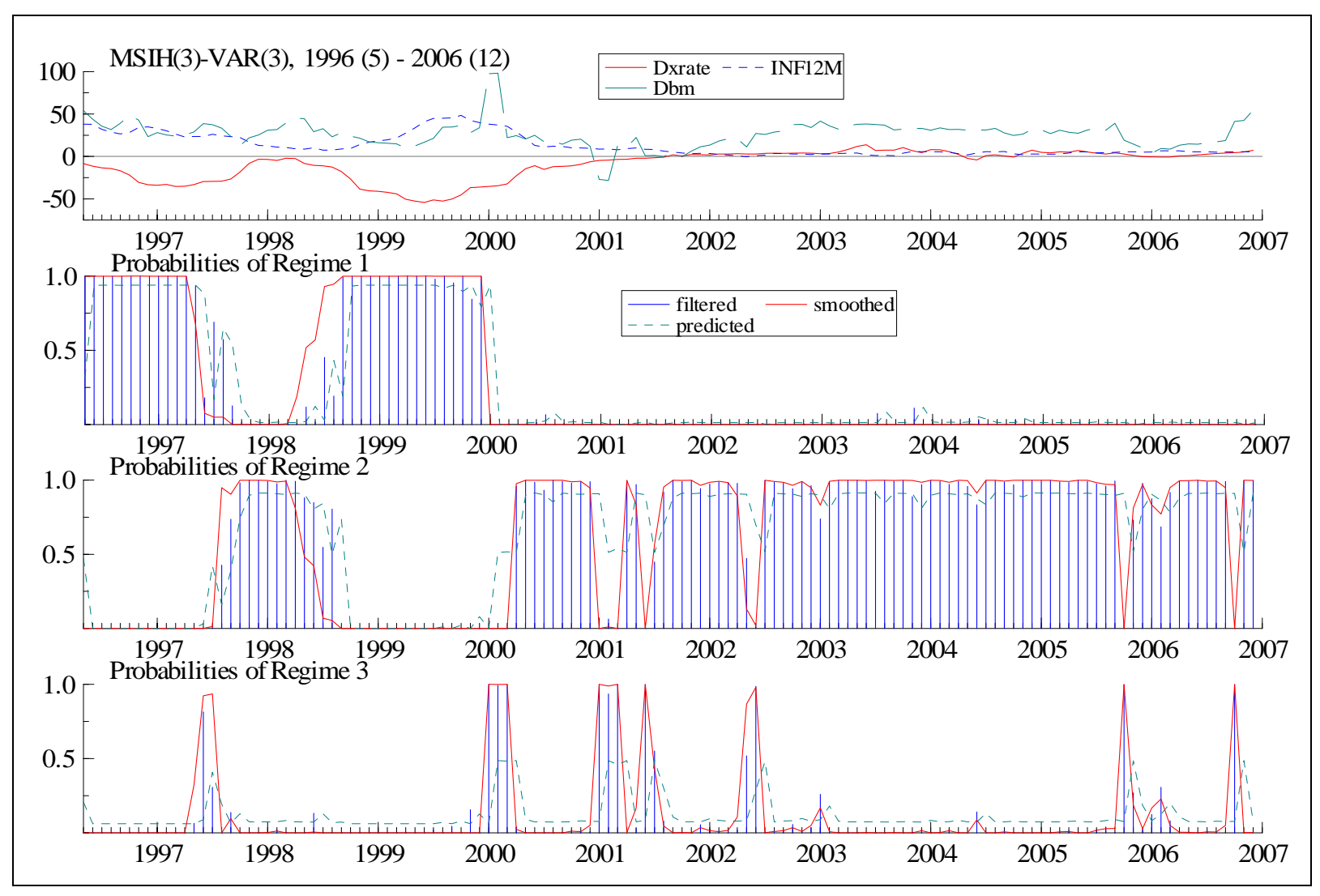

Source: Author's estimations using the Expectations-Maximization (EM) algorithm in Ox.

\section{Impulse-response analysis}

To uncover the dynamic relationship among money growth, inflation, and exchange rate movements, we adopt two well-known approaches. First, we consider the regime-dependent impulse response functions derived from the MSIH(3)-VAR(3) model. Second, we follow Krolzig and Toro, 1999 and characterize changes in these variables in the transition across regimes.

The estimated regime-dependent impulse response functions support theoretical predictions. Three results stand out. First, as depicted in the third column of Figure 4, a positive shock to money tends to increase inflation and depreciate the domestic currency, irrespective of the regime. Second, in the regime of appreciation pressure (regime 3) an increase in inflation, which is associated with monetary expansion, drives exchange rate depreciation. However, a similar shock in the first and second regimes yields a counter intuitive result-it appreciates the currency. Lastly, a positive exchange rate shock (or appreciation) in all regimes tends to be associated with a decline in inflation; money growth declines only with a lag. 
Figure 4. Regime-dependent Impulse Response Functions

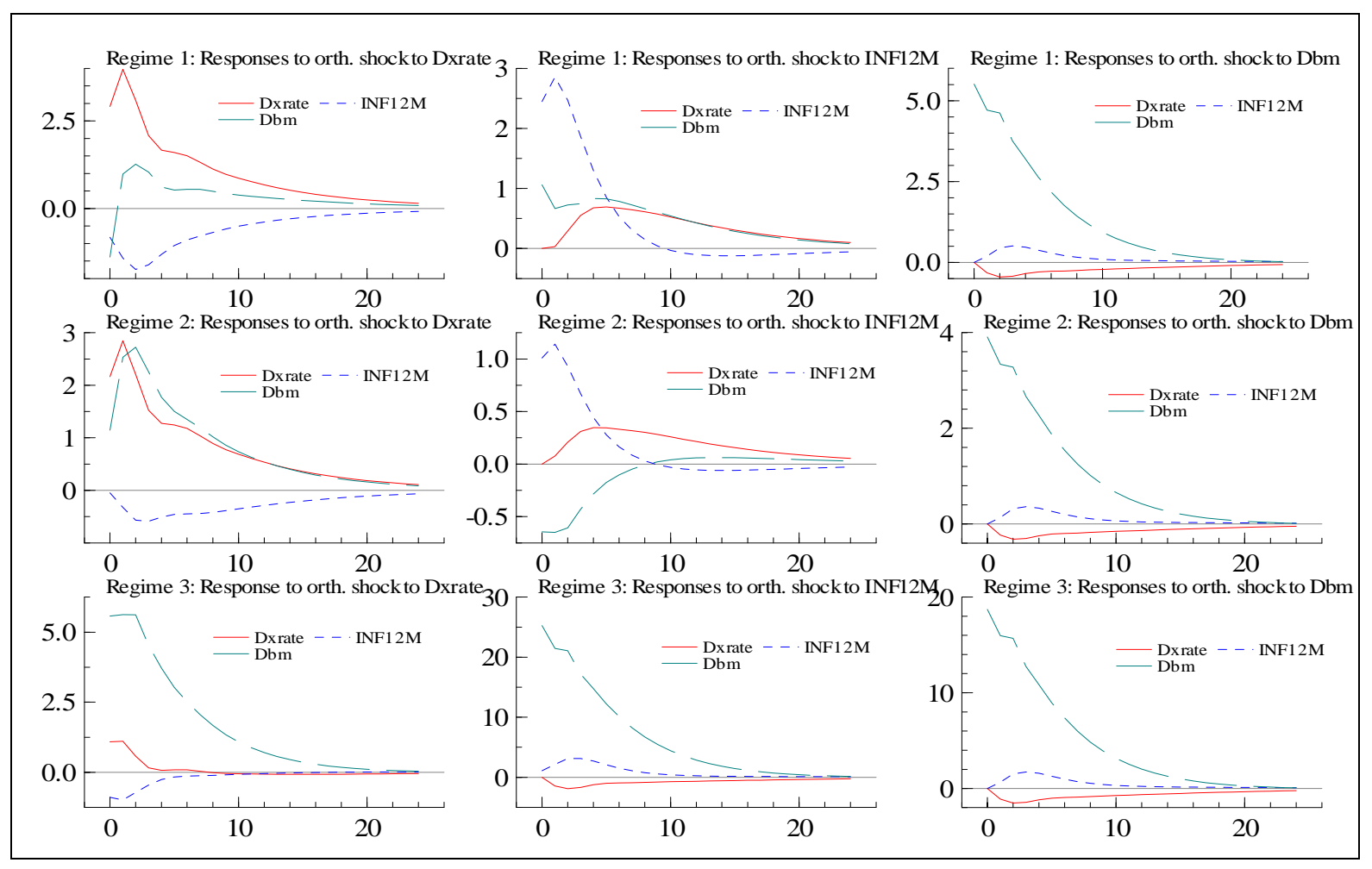

Source: Author's estimations.

\section{Regime shifts and impulse responses}

In the context of regime-switching models, it is feasible to analyze co-movements among variables during the various phases of identified regimes. In addition to the responses of the variables to Gaussian innovations, researchers are also able to investigate the dynamics of the variables in the transition for example from booms to slumps-and in our case, we investigate the dynamics of the system in the transition among the three regimes. The responses during the transitions of the state variables depend essentially on the properties of the VAR and the unobserved Markov chain. In our particular model with regime-dependent variances but autoregressive coefficients that are constant across regimes, the dynamics are characterized by changes in the current state and the conditional expectation of a future regime, which are in turn highly dependent on our state variable (STATES $_{\mathrm{F}}$, derived using Table 1 and equation (10)).

The results of the regime shift exercise (shown in Figure 5 below) yield four main results, as summarized below. We characterize the behavior of the variables for each of the three regimes identified by the ergodic regime probability distributions presented in Figure 2 above.

- $\quad$ First, the setup correctly captures depreciation and appreciation pressures in regimes 1 and 3, respectively, as shown in the responses along the diagonal of Figure 5. 
Further, an increase in inflation tends to be associated with exchange rate depreciation in regime 1, just as a decline in inflation drives exchange rate appreciation in regime 3 . In regime 2 (normal exchange rate changes) exchange rate appreciation tends to be associated with a decline in inflation and moderate money growth.

- $\quad$ Second, in the transition from regime 1 (appreciation pressure) to either regime 2 (normal exchange rate changes) or regime 3 (depreciation pressure) exchange rate appreciation tends to be associated with moderate money growth and decline in inflation.

- $\quad$ Third, increasing inflation drives exchange rate depreciation during the transition from regimes 2 and 3 to regime 1 .

- $\quad$ Fourth, exchange rate appreciation tends to be associated with declining inflation and moderate money growth in the transition from regime 2 to regime 3 ; in the reverse direction, increasing inflation drives exchange rate depreciation.

Figure 5. Response of the System after Regime Shifts

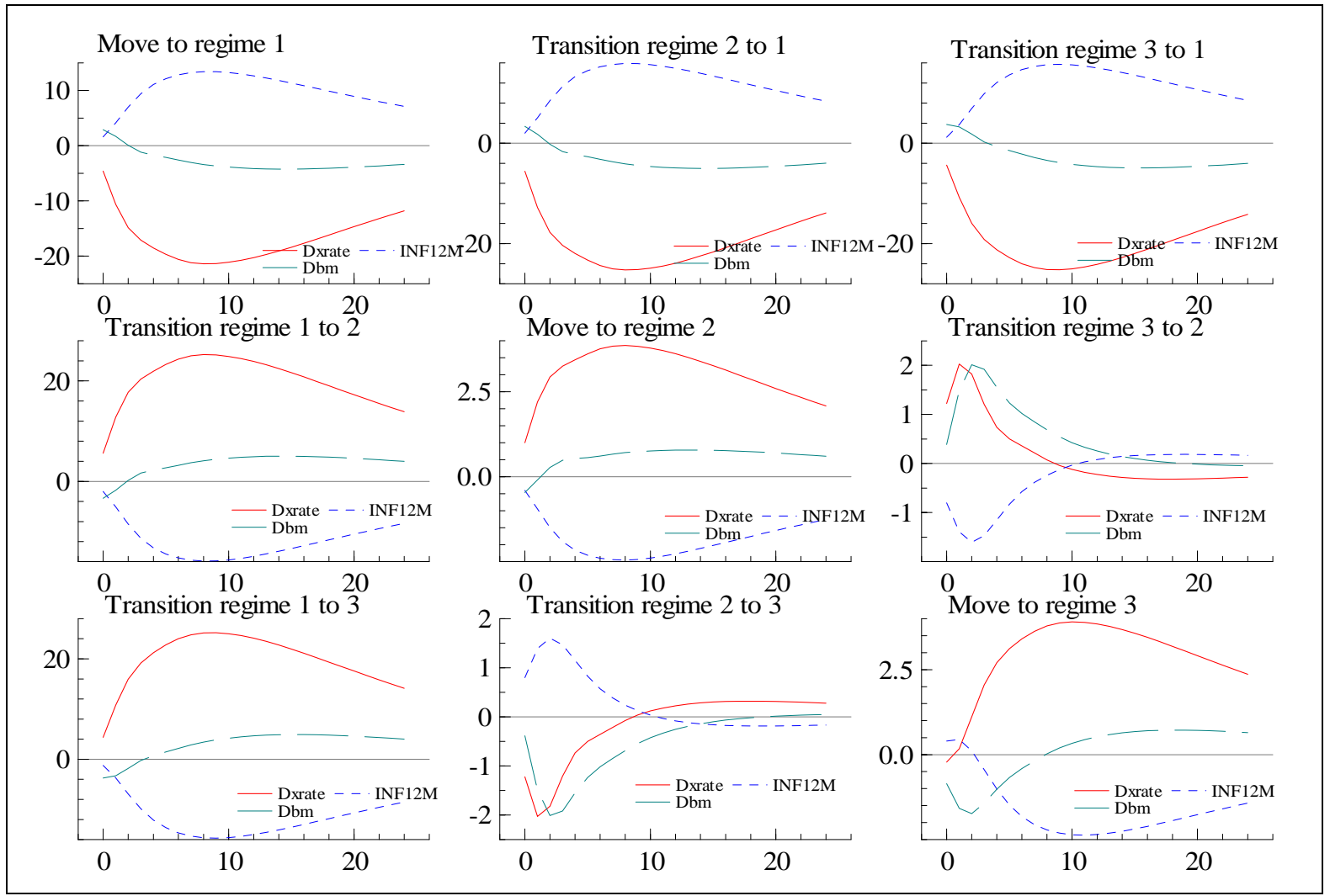

Source: Author's estimations. 


\section{CONCLUSION}

This paper adds to the literature on exchange market pressure. Its main contribution is the formalization and estimation of exchange market pressure as a nonlinear process. The paper uses Markov-switching econometric methods and data on the Kyrgyz Republic to identify and characterize three regimes of exchange rate movements during 1996-2006. While it is certainly not a pioneer in applying a regime-switching model to exchange rate movements, it is to our knowlegde the first to explicitly formalize exchange market pressure as a nonlinear phenomenon and then use regime-switching econometric methods to investigate its dymanics over identified regimes.

The results from the paper confirm the relationship among money growth, inflation and exchange rate changes during periods of exchange market pressure and in the transition to and from these periods. More importantly, they confirm the statistical biasedness of linear estimation methods, such as linear VAR approaches, and underscore the superiority of regime-switching models in understanding the dynamics of exchange market pressure. It turns out that the nonlinear approach yields a congruent representation of the data generation process and theory-consistent empirical results. In particular, in contrast to findings of earlier research using linear specifications, our results confirm the theorectical prediction of a dampening effect of contractionary monetary policy (or equivalently, interest rate increases) on depreciation pressure, but the reverse may not be an efficient policy option during periods of appreciation pressure, particularly in countries where uncovered interest parity does not seem to drive exchange rates. This is because monetary expansion in such cases defeats the primary objective of monetary policy-price stability-and could introduce further instability into the foreign exchange market.

The empirical results offer the following policy lesson to the Kyrgyz Republic in its search for a policy mix to contain inflation and appreciation pressure: limiting unsterilized interventions in the foreign exchange market will help dampen inflation, albeit with some appreciation of the domestic currency, the som. Alternatively, maintaining the current rate of interventions (i.e. net purchases of foreign exchange), but increasingly sterilizing its impact on monetary aggregates will help reduce inflation and allow further appreciation of the domestic currency, but by a lower margin than under the first option. However, other policy instruments (including measures to improve the business environment and reduce the costs of doing business) will need to be synchronized with the above to safeguard external competetiveness. 


\section{APPENDIX I. DATA SOURCES AND TRANSFORMATIONS}

All data used in this analysis are from the IMF's International Financial Statistics supplemented by intervention data provided by the Kyrgyz authorities. The data are monthly covering the period January 1996-December 2006. The following variables are used in the paper:

1) $e_{t}$ : logarithm of the exchange rate of the som to the US dollar, expressed as dollars per som so that an increase indicates appreciation (unless otherwise indicated in section II). $\Delta e_{t}$ denotes 12-month percent change in the exchange rate, which is also indicated in Figures $3-5$ as Dxrate;

2) $\quad p_{t}$ : is the logarithm of the consumer price index, such that $\Delta p_{t}$ denotes $12-$ month inflation, which is indicated in Figures 3-5 as INF12M;

3) $m_{t}$ : is the logarithm of broad money (M2), such that $\Delta m_{t}$ denotes the rate of money growth, which is also indicated in Figure 3-5 as Dbm;

4) STATES $S_{\mathrm{F}}$ : A state (or dummy) variable that takes on the values of 0 , 1 , or 2, depending on whether the EMP indicator described in Table 1 points to depreciation pressure, normal exchange rate movements, or appreciation pressure, respectively. 


\section{Appendix II. Model Performance and Duration Probabilities}

Figure A1: The fit of the Markov-switching VAR

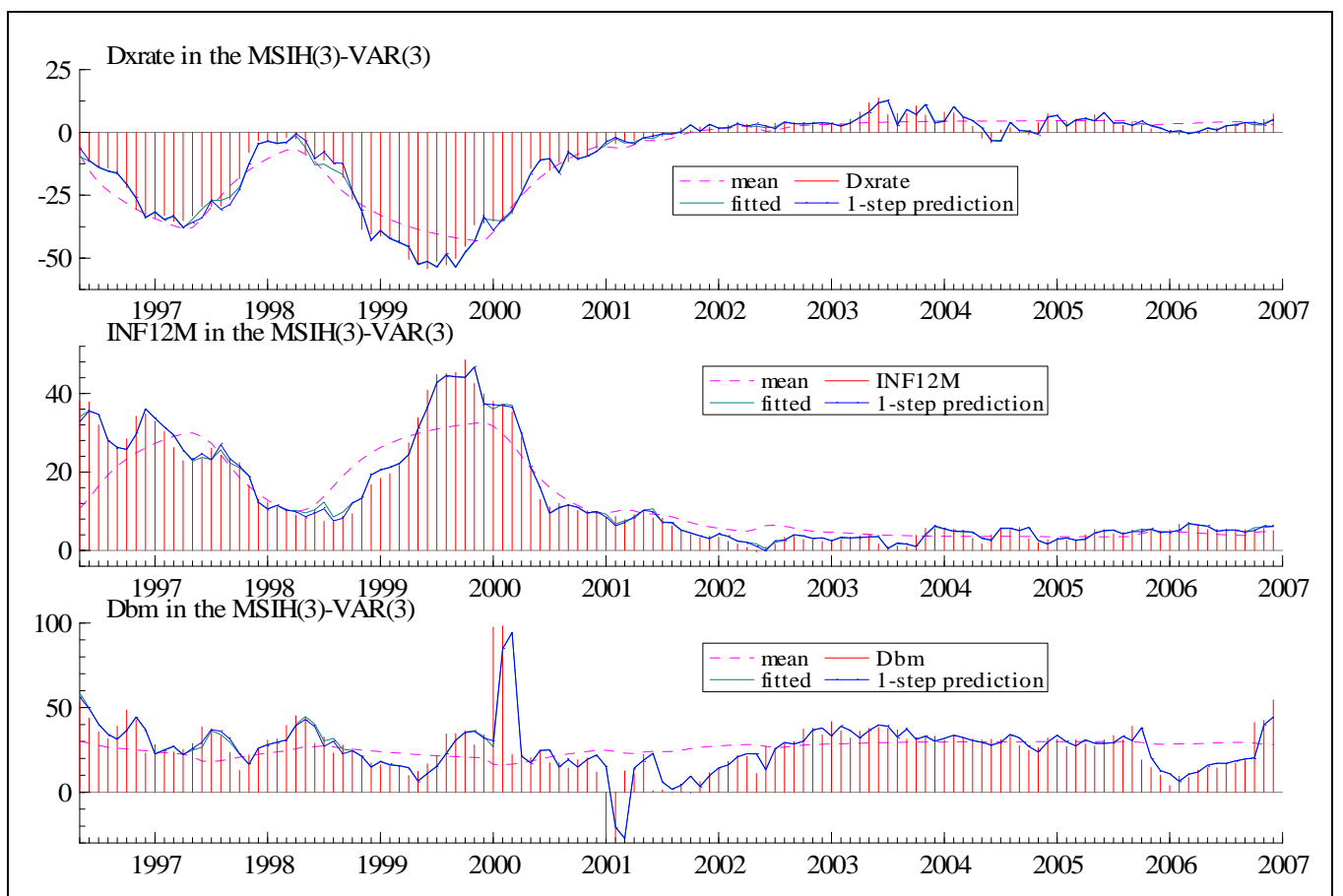

Source: Author’s estimations.

Figure A2. Residuals from the Markov-switching VAR.

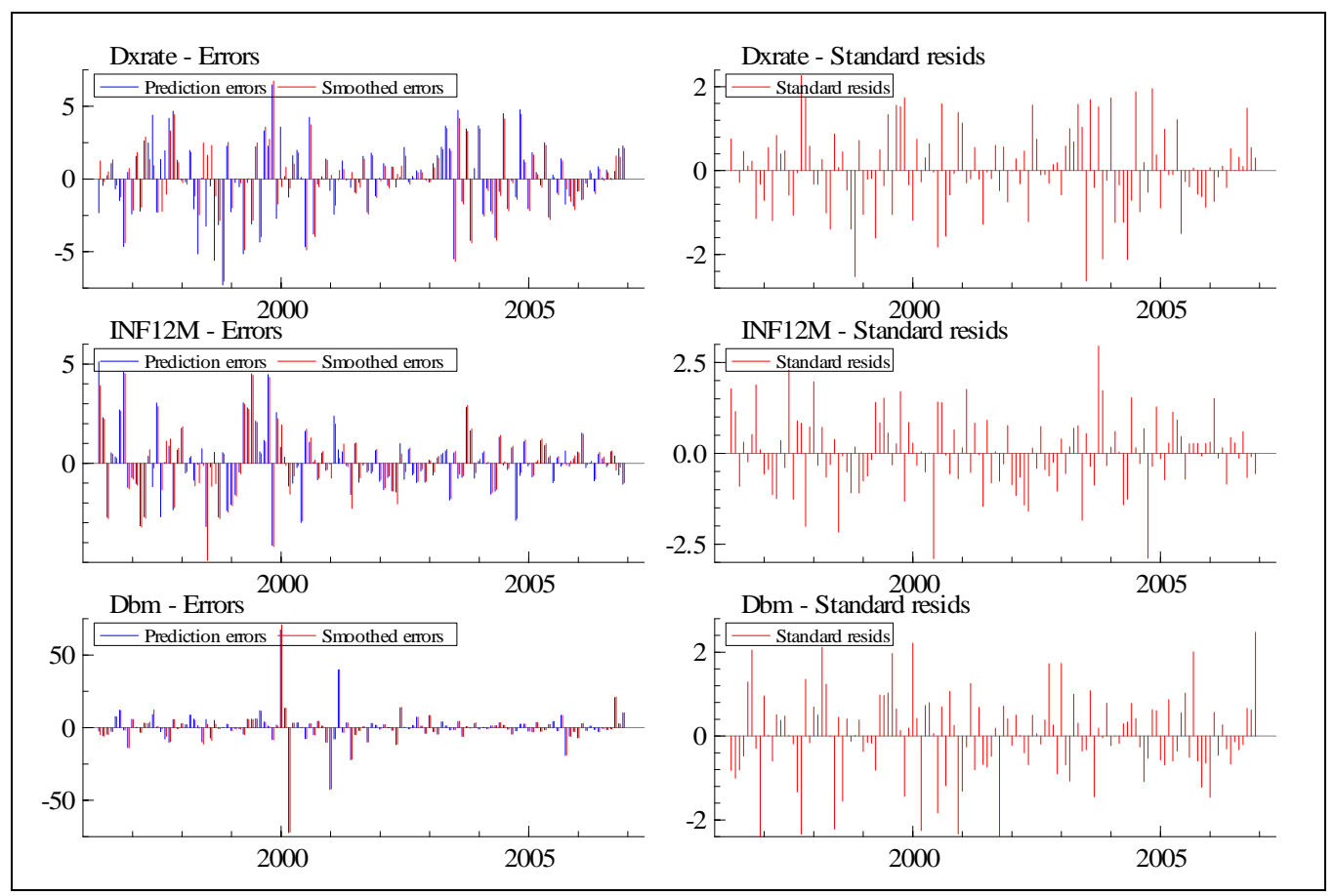

Source: Author's estimations. 
Figure A3. Statistical characteristics of residuals from the Markov-switching VAR.

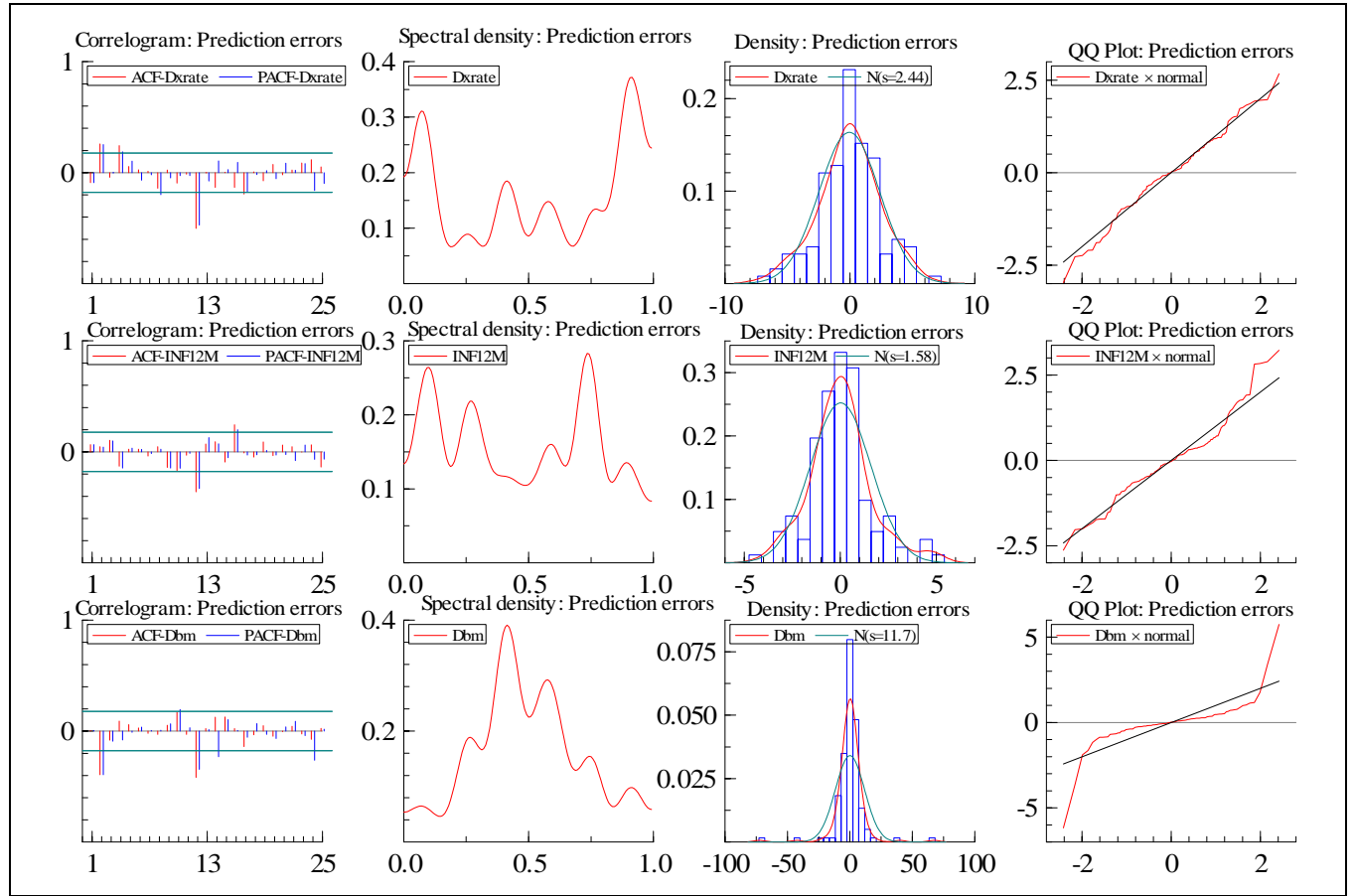

Source: Author's estimations.

Figure A4: Predicted $h$-step ahead probabilities and duration probabilities

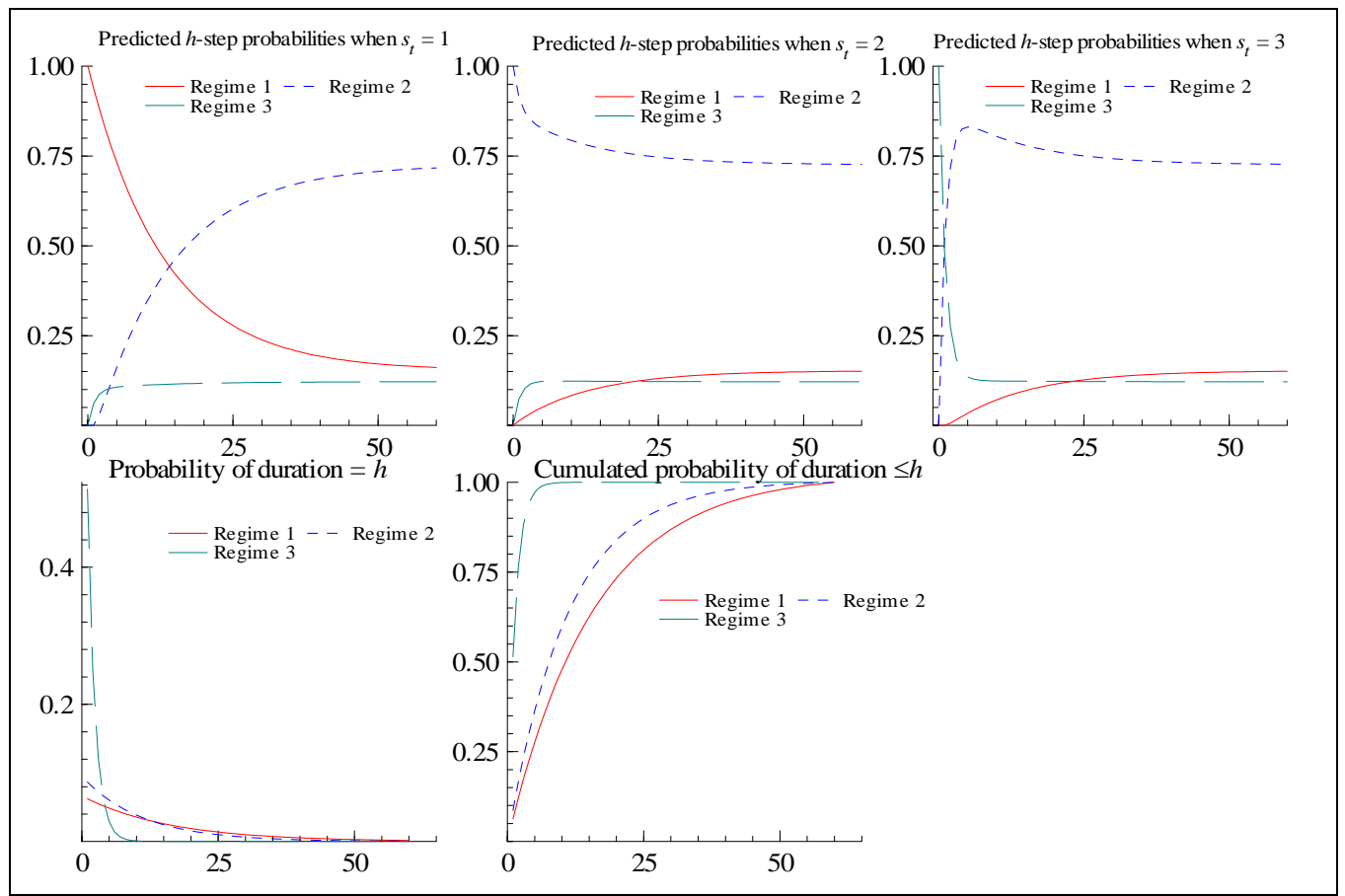

Source: Author’s estimations. 


\section{References}

Branson, W. H. and Dale W. Hendersen, 1985, "The Specification and Influence of Asset Markets,” in Jones and Kenen, 1985, eds. Handbook of International Economics, pp. 745-805.

Cerra, Valerie and Sweta C. Saxena, 2002, "Contagion Monsoons, and Domestic Turmoil in Indonesia’s Currency Crisis,” Review of International Economics, 10(1), pp. 36-44.

Chen, Shiu-Sheng, 2006, "Revisiting the Interest Rate-Exchange Rate Nexus: A Markovswitching approach,” Journal of Development Economics, Vol. 79, pp. 208-224.

Doornik, J. A., 1999, Object-oriented Matrix Programming using Ox, London: Timberlake Consultatnts, Third Edition.

Dornbusch, Rudiger, 1976, “Expectations and Exchange Rate Dynamics,” Journal of Political Economy, 84(6), pp. 1161-1175.

Edwards, Sebastian, 2002, “Does the Current Account Matter?” In: Edwards, S. and J. A. Frankel (eds.), 2002, Preventing Currency Crises in Emerging Markets, The University of Chicago Press, Chicago and London.

Eichengreen, B., Rose, A. K., and Wyplosz, C., 1994, “Speculative Attacks on Pegged Exchange Rates: An Empirical Exploration with Special Reference to the European Monetary System,” NBER Working Paper No. 4898.

Eichengreen, B., Rose, A. K., and Wyplosz, C., 1995, "Exchange Market Mayhem: The Antecedents and Aftermath of Speculative Attacks,” Economic Policy 21 (October), pp. 249-312.

Furman, Jason and Joseph Stiglitz, 1998, "Economic Crises: Evidence and Insights from East Asia,”(unpublished; World Bank, Washington, DC.). Presented at Brookings Panel on Economic Activity, September 4, 1998.

Girton, Lance and Don Roper, 1977, “A Monetary Model of Exchange Market Pressure Applied to the Postwar Canadian Experience,” American Economic Review Vol. 67, pp. 537-48.

Goldfajn, Ilan and Poonam Gupta, 1998, "Does Tight Monetary Policy Stabilize the Exchange Rate Following a Currency Crisis?” IMF Working Paper No. WP/99/42 (Washington; Internatonal Monetary Fund).

Hamilton, James D. 1989, “A New Approach to the Economic Analysis of Nonstationary Time Series and the Business Cycle,” Econometrica, Vol. 57. No. 2, pp. 357-384.

Hamilton, James D. 1990, "Long Swings in the Dollar: Are They in the Data and Do Markets Know It?” American Economic Review, Vol. 80. No. 4, pp. 689-713. 
Krolzig, Hans-Martin, 1998, “Econometric Modeling of Markov-switching Vector Autoregressions using MSVAR for Ox,” Discussion Paper, Institute of Economics and Statistics, University of Oxford.

Krolzig, Hans-Martin and Juan Toro, 1999, “A New Approach to the Analysis of Business Cycle Transitions in a Model of Output and Employment,” European University Institute, Working Paper No. 99/30, pp. 1-27.

Krolzig, Hans-Martin, Massimiliano Marcellino, and Grayham E. Mizon, 2002, “A MarkovSwitching Vector Equilibruim Correction Model of the UK Labour Market,” Empirical Economics, 27, pp. 233-254.

Pentecost, Eric J., Charlotte van Hooydonk and André van Poeck, 2001, "Measuring and Estimating Exchange Market Pressure in the EU,” Journal of International Money and Finance 20, pp. 401-18.

Radelet, Steven, Jeffery D. Sachs, Richard N. Cooper, and Barry P. Bosworth, 1998, "The East Aisan Financial Crisis: Diagnoses, Remedies, Prospects,” Brookings Papers on Economic Activity No. 1, pp. 1-90.

Soledad, Maria and Peria Martinez 2002, “A Regime-Switching Approach to the Study of Speculative Attacks: A Focus on the EMS crises,” Empirical Economics, Vol. 27, pp. 299-334

Tanner, Evan, 2001, “Exchange Market Pressure and Monetary Policy: Asia and Latin America in the 1990s,” IMF Staff Papers, Vol. 47, pp. 311-33.

Tanner, Evan, 2002, “Exchange Market Pressure, Currency Crisis, and Monetary Policy: Additional Evidence from Emerging Markets,” IMF Working Paper No. WP/02/14.

Weymark, D. N., 1995, “Estimating Exchange Market Pressure and the Degree of Exchange Market Intervention for Canada,” Journal of International Economics, 39, pp. 249272.

— 1 1997a, "Measuring the Degree of Exchange Market Intervention in a Small Open Economy,” Journal of International Money and Finance, 16, pp. 55-79.

_ 1 1997b, "Measuring Exchange Market Pressure and Intervention in Interdependent Economies: A Two-Country Model,” Review of International Economics Vol. 5(1), pp. 72-82.

—_ 1998, “A General Approach to Measuring Exchange Market Pressure,” Oxford Economic Papers, Vol. 50, pp. 106-121. 